Saudi Journal of Biomedical Research

Abbreviated Key Title: Saudi J Biomed Res ISSN 2518-3214 (Print) |ISSN 2518-3222 (Online) Scholars Middle East Publishers, Dubai, United Arab Emirates Journal homepage: https://saudijournals.com

\title{
VDRL Seropositivity in Blood Donors in Sudan's North Darfur State-2019
}

Mohammed Ahmed Ibrahim Ahmed ${ }^{1 *}$, Nassreldeen Khalid Abdelrahman ${ }^{2}$, Mosab Nouraldein Mohammed Hamad ${ }^{3}$, Nahla Ahmed Mohammed Abdelrahman ${ }^{4}$, Marawa Ahmed Mohammed Abd Erahman ${ }^{5}$

${ }^{1,}{ }^{4}$ Nile Valley University - Faculty of Medicine, Atbara, Sudan

${ }^{2}$ University of Al Fashir - Faculty of Medical Laboratory Science, Sudan

${ }^{3}$ Phylum of Medical Parasitology, Department of Medical Laboratory Sciences, Faculty of Health Science, Elsheikh Abdallah Elbadri University, Berber, Sudan

${ }^{5}$ Dermatologist - Ministry of health- Khartoum State, Sudan

DOI: $10.36348 /$ sjbr.2021.v06i04.003 $\quad$ | Received: 23.02.2021 | Accepted: 11.04.2021 | Published: 21.04 .2021

*Corresponding author: Dr. Mohammed Ahmed Ibrahim Ahmed

\section{Abstract}

Objective: The aim of this research was to ascertain how often blood donors were VDRL seropositive and whether there was a connection between syphilis serological evidence and age as well as residency. Methods: A retrospective analysis of sequentially blood donor documents from January to December 2019 was performed out in North Darfur State, Western Sudan. The analytical descriptions wre computed using percentages. Chi-square was used to analyze trends and quantify p-values. Results: There were a total of 6100 enthusiastic blood donors, all of whom were males between the ages of 15 and 55; the average age was 29.5 years. VDRL screenings for syphilis indicated that 794 of them (13.0\%) had serological evidence of syphilis, and the remainder $50306(78 \%)$ were negative. A strong association was found between residency and serological evidence of syphilis infection in the study $(\mathbf{P}=\mathbf{0 . 0 0 0})$. Age was shown to be a strong predictor of the occurrence of transfusion transmissible infections $(\mathrm{P}=0.002)$. When opposed towards the other age categories, the (21-25) and (26-30) year age ranges had a higher incidence. 239/1551 (15.4\%), 140/1089(12.8\%) were positive respectively. Conclusions: There seems to be an increasing proportion of sero-positive VDRL in blood donations in North Darfur State. An association between syphilis infection and residency was realized, as well as a high prevalence within a particular age demographic with a statistically meaningful correlation.

Keywords: Syphilis; VDRL; Blood donors; Darfur; Sudan.

Copyright (C) 2021 The Author(s): This is an open-access article distributed under the terms of the Creative Commons Attribution 4.0 International License (CC BY-NC 4.0) which permits unrestricted use, distribution, and reproduction in any medium for non-commercial use provided the original author and source are credited.

\section{INTRODUCTION}

Transfusion-transmissible infections (TTIs) are known as the most potential problems to blood transfusion safety for recipients, posing potentially serious concerns [1].

Blood donation is a life-saving approach that does save millions of people's lives annually around the globe. Blood transfusions, on the other hand, are faced with a multitude of potential consequences that can lead to adverse outcomes. It may cause acute or delayed complications and carries the risk of the trans- mission of infections. Globally, more than 81 million units of blood are donated each year [2].

There is no authentic substitute for blood transfusion, so it is a therapeutic procedure. Even so, a contaminated blood donation can propagated infectious diseases and be fatal instead of just saving lives [3].
Data on the incidence of transfusion transmissible infections (TTIs), such as HIV, HBV, $\mathrm{HCV}$, and syphilis antibodies between several blood and plasma donors, is being used to evaluate the onset of infections in the blood donor population and, as a consequence, the safety of the collected donations. It also provides information on the community's epidemiology of these diseases. Infections caused by blood transfusions remain a major challenge. Syphilis is less commonly conveyed through blood, and most studies highlight that the incidence is limited [4].

Treponema palladium causes syphilis, a systemic disease distributed by sexual contact, blood transfusion, as well as mother to child transmission [5].Syphilis is really a major public health issue in SubSaharan Africa. Syphilis has indeed created a greater morbidity and mortality serious risk to its correlation with an increased risk of HIV infection [6] 
Calculating the burden of TTIs, specifically $\mathrm{HBV}, \mathrm{HCV}, \mathrm{HIV}$, and syphilis antibodies or antigens, Blood donation among healthfully members of the community will expose the issue of overlooked infections, as well as have evidence that is useful in developing methods for optimizing blood supply management. Furthermore, it will provide us with an indication of the severity of certain sexually transmitted infections in the community [7].

\section{MATERIALS AND METHODS Study Design}

This cross-sectional hospital-based study was held between January and December 2019 among blood donors at El fashir Main Blood Center.

\section{Study Area}

The investigation was carried out in Elfashir Zone, the capital of North Darfur State (residing between longitudes 31.5-34 east and latitude 15-16 north), which has an area of approximately 28.165 square kilometers.s

\section{Study Population}

During the study period, all blood donors, whether volunteers or relatives or friends of recipients, were invited to fill a standardized questionnaire containing socio-demographic facts. (age, gender, and state of residence), previous disease and medical problem, blood transfusion experience, and jaundice. Those that tend to be in better health and were between ages of 18 and 55 are eligible to donate blood.

\section{Study variable}

The syphilis test result was the dependent variable in this report, whereas the independent variables were residency and age.

\section{Sample Size and Data Collection}

Five milliliters of blood were pulled from each subject, sera were extracted, and syphilis non-specific antibodies were screened at the venereal disease research laboratory (VDRL) with a quick Dip-strip (manufactured in the UK by fortress diagnostic LTD). Blood was retrieved from 6100 blood doors in free anticoagulant clear tubes, and details such as age and ethnicity of all participants were acquired using a standardized interview questionnaire. The study's purposes were clarified to all respondents, and their verbal consent was achieved.

\section{Ethical Approve}

The ethics known performance from the Ministry of Health. Fore being enrolled in the study, all respondents were asked to report their consent. This study required all participants to provide information.

\section{DATA ANALYSIS}

For entering data and analysis of the volunteers' characteristics, the Statistical Package for Social Sciences program (SPSS Inc., Chicago, IL, USA) version 20 was used. Incredibly simple descriptive statistics were used to analyze the laboratory results of the VDRL test as well as demographic data. Any two variables were compared using the Chi-square test. A p value of less than 0.05 was considered statistically acceptable.

\section{RESULTS}

This study enrolled 6100 male blood donors from various localities in North Darfur Region, with an average age of 29.5 years. The participants' ages ranged from 15 to 55 years. VDRL positivity was reported to be $13.0 \%(794 / 6100)$ Table 1.

The findings revealed a significantly important association between syphilis and age $(\mathrm{P}=0.002)$, with the plurality of positive serological evidence of syphilis within the ages of (15-20) and (21-25) years being 239/1551 (15.4\%) and 140/1089 (12.8\%), respectively. Table 2 There had been a significantly positive association between syphilis serological proof and state of residence $(\mathrm{P}=0.000)$ Table 3 .

Table-1: Distribution of VDRL test:

\begin{tabular}{|l|l|}
\hline Frequency & Percent \\
\hline 794 & 13.0 \\
\hline 5306 & 87.0 \\
\hline 6100 & 100.0 \\
\hline
\end{tabular}


Mohammed Ahmed Ibrahim Ahmed et al., Saudi J Biomed Res, Apr, 2021; 6(4): 63-66

Table-2: Age group and Syphilis Cross-tabulation

\begin{tabular}{|c|c|c|c|c|c|}
\hline \multirow{2}{*}{\multicolumn{2}{|c|}{ Age group }} & \multicolumn{2}{|l|}{ Syphilis } & \multirow[t]{2}{*}{ Total } & \multirow[t]{2}{*}{$P$ value } \\
\hline & & Positive & Negative & & \\
\hline \multirow[t]{3}{*}{$15-20$} & Count & 55 & 422 & 477 & \multirow{21}{*}{0.002} \\
\hline & $\%$ within Age group & $11.5 \%$ & $88.5 \%$ & $100.0 \%$ & \\
\hline & $\%$ within Syphilis & $6.9 \%$ & $8.0 \%$ & $7.8 \%$ & \\
\hline \multirow[t]{3}{*}{$21-25$} & Count & 239 & 1570 & 1809 & \\
\hline & $\%$ within Age group & $13.2 \%$ & $86.8 \%$ & $100.0 \%$ & \\
\hline & $\%$ within Syphilis & $30.1 \%$ & $29.6 \%$ & $29.7 \%$ & \\
\hline \multirow[t]{3}{*}{$26-30$} & Count & 239 & 1312 & 1551 & \\
\hline & $\%$ within Age group & $15.4 \%$ & $84.6 \%$ & $100.0 \%$ & \\
\hline & $\%$ within Syphilis & $30.1 \%$ & $24.7 \%$ & $25.4 \%$ & \\
\hline \multirow[t]{3}{*}{$31-35$} & Count & 140 & 949 & 1089 & \\
\hline & $\%$ within Age group & $12.9 \%$ & $87.1 \%$ & $100.0 \%$ & \\
\hline & $\%$ within Syphilis & $17.6 \%$ & $17.9 \%$ & $17.9 \%$ & \\
\hline \multirow[t]{3}{*}{$36-40$} & Count & 75 & 557 & 632 & \\
\hline & $\%$ within Age group & $11.9 \%$ & $88.1 \%$ & $100.0 \%$ & \\
\hline & $\%$ within Syphilis & $9.4 \%$ & $10.5 \%$ & $10.4 \%$ & \\
\hline \multirow{3}{*}{$\begin{array}{l}\text { More } \\
\text { than } 40\end{array}$} & Count & 46 & 496 & 542 & \\
\hline & $\%$ within Age group & $8.5 \%$ & $91.5 \%$ & $100.0 \%$ & \\
\hline & $\%$ within Syphilis & $5.8 \%$ & $9.3 \%$ & $8.9 \%$ & \\
\hline \multirow[t]{3}{*}{ Total } & Count & 794 & 5306 & 6100 & \\
\hline & $\%$ within Age group & $13.0 \%$ & $87.0 \%$ & $100.0 \%$ & \\
\hline & $\%$ within Syphilis & $100.0 \%$ & $100.0 \%$ & $100.0 \%$ & \\
\hline
\end{tabular}

Table-3: Residence and Syphilis Cross-tabulation

\begin{tabular}{|c|c|c|c|c|c|}
\hline \multicolumn{2}{|l|}{ Residence } & \multicolumn{2}{|l|}{ Syphilis } & \multirow[t]{2}{*}{ Total } & \multirow[t]{2}{*}{ P value } \\
\hline & & Positive & Negative & & \\
\hline \multirow[t]{3}{*}{ Kutoum } & Count & 14 & 89 & 103 & \multirow{21}{*}{0.000} \\
\hline & $\%$ within Residence & $13.6 \%$ & $68.4 \%$ & $100.0 \%$ & \\
\hline & $\%$ within Syphilis & $1.8 \%$ & $1.7 \%$ & $1.7 \%$ & \\
\hline \multirow[t]{3}{*}{ Camp } & Count & 189 & 892 & 1081 & \\
\hline & $\%$ within Residence & $17.5 \%$ & $82.5 \%$ & $100.0 \%$ & \\
\hline & $\%$ within Syphilis & $23.8 \%$ & $16.8 \%$ & $17.7 \%$ & \\
\hline \multirow[t]{3}{*}{ Elfashir } & Count & 549 & 4074 & 4623 & \\
\hline & $\%$ within Residence & $11.9 \%$ & $88.1 \%$ & $100.0 \%$ & \\
\hline & $\%$ within Syphilis & $69.1 \%$ & $76.8 \%$ & $75.8 \%$ & \\
\hline \multirow[t]{3}{*}{ Malit } & Count & 8 & 61 & 69 & \\
\hline & $\%$ within Residence & $11.6 \%$ & $88.4 \%$ & $100.0 \%$ & \\
\hline & $\%$ within Syphilis & $1.0 \%$ & $1.1 \%$ & $1.1 \%$ & \\
\hline \multirow[t]{3}{*}{ Kabkabia } & Count & 5 & 47 & 52 & \\
\hline & $\%$ within Residence & $9.6 \%$ & $90.4 \%$ & $100.0 \%$ & \\
\hline & $\%$ within Syphilis & $0.6 \%$ & $0.9 \%$ & $0.9 \%$ & \\
\hline \multirow[t]{3}{*}{ Others } & Count & 29 & 143 & 172 & \\
\hline & $\%$ within Residence & $3.6 \%$ & $96.4 \%$ & $100.0 \%$ & \\
\hline & $\%$ within Syphilis & $3.7 \%$ & $2.7 \%$ & $2.8 \%$ & \\
\hline \multirow[t]{3}{*}{ Total } & Count & 794 & 5306 & 6100 & \\
\hline & $\%$ within Residence & $13.0 \%$ & $87.0 \%$ & $100.0 \%$ & \\
\hline & $\%$ within Syphilis & $100.0 \%$ & $100.0 \%$ & $100.0 \%$ & \\
\hline
\end{tabular}

\section{DISCUSSION}

In our analysis, the occurrence of syphilis serological evidence was 13.0 percent, which was greater than in previous studies in White Nile StateSudan $(6.8 \%)$ [5].In addition, a study performed in Eastern Ethiopia noticed syphilis prevalence among blood donors $(0.1 \%)$ [9].This result in the current study could become attributed to a lack of standard health care facilities, as well as wars and forced relocations that have occurred in this sector since 2002.

The age groups between (15 and 20) and (21 and 25) years old had the highest incidence of syphilis infection, with substantial cross-tabulation $(\mathrm{p}=0.002)$. This finding contradicted a study conducted in Kosti White Nile Province, Sudan, which found a high 
Mohammed Ahmed Ibrahim Ahmed et al., Saudi J Biomed Res, Apr, 2021; 6(4): 63-66

prevalence of infection among people aged 20 to 40 [8].This conclusion may be considered an indicator of sexual maturity and reproduction due to environmental differences between central and western Sudan.

In our report, there was a statistically important part of a relationship between syphilis infection and residency $(\mathrm{p}=0.000)$. This awareness was confirmed by another report commissioned in Rwanda, which stated the cross-tabulation of syphilis and rural households with a scarcity of healthcare facilities [10].

For the aforementioned reasons, a single positive result was considered positive. There was no confirmatory checking. As a consequence, false positives cannot be ruled out, and true infectious disease rates could be lower than documented; these are called constraints of the ongoing study.

\section{CONFLICTS OF INTEREST}

There are no potential conflicts in this report, per the researchers.

\section{AUTHORS' CONTRIBUTIONS}

The authors contributed equally to the design of the study and the writing of the manuscript. The final edition of the manuscript was read and accepted by all members.

\section{ACKNOWLEDGMENTS}

We would like to express our sincere appreciation thanks to all of the research respondents. The authors wish to thank the medical staff at Elfashir Teaching Hospital. We are indebted to the Elfashir centralized blood bank representatives for their professional assistance.

\section{REFERENCES}

1. Tessema, B., Yismaw, G., Kassu, A., Amsalu, A., Mulu, A., Emmrich, F., \& Sack, U. (2010). Seroprevalence of HIV, HBV, HCV and syphilis infections among blood donors at Gondar University Teaching Hospital, Northwest Ethiopia: declining trends over a period of five years. BMC Infectious diseases, 10(1), 1-7.

2. Manzoor, I., Hashmi, N., Daud, S. E. E. M. A., Ajmal, S. A. N. A., Fatima, H., Rasheed, Z. A. I. N. A. B., \& Syed, S. A. (2009). Seroprevalence of transfusion transmissible infections (TTIS) in blood donors. Biomedica, 25(10), 154-8.

3. Fessehaye, N., Naik, D., \& Fessehaye, T. (2011). Transfusion transmitted infections-A retrospective analysis from the National Blood Transfusion Service in Eritrea. Pan African Medical Journal, 9(1).

4. Bhawani, Y., Rao, P. R., \& Sudhakar, V. (2010). Seroprevalence of transfusion transmissible infections among blood donors in a tertiary care hospital of Andhra Pradesh. Biol Med, 2(4), 45-48.

5. Murray, P., Rosenthal, K., Kobayashi, G., Pfaller, M. (2002). Medical microbiology, 4: 379-380.

6. Olokoba, A. B., Olokoba, L. B., Salawu, F. K., Danburam, A., Desalu, O. O., Badung, L. H., ... \& Abdulkarim, A. (2009). Syphilis in voluntary blood donors in North-Eastern Nigeria. Eur J Sci Res, 31(3), 335-340.

7. Singh, R., Vohra, P., Singla, P., \& Chaudhary, U. (2013). Seroprevalence of transfusion transmissible infections among healthy blood donors at general hospital, Sonepat, North India. J Evol Med Dent Sci, 2(26), 4816-20.

8. Bazie, E. A., Ali, M. M. A., Hamza, H. B., Magzoub, O. S., Salih, M. S. M., Haroun, B. E., \& Malik, M. F. K. (2015). Sero-Prevalence of HIV and Syphilis Infections among Blood Donors at Kosti Teaching Hospital-White Nile State-Sudan.

9. Mohammed, Y., \& Bekele, A. (2016). Seroprevalence of transfusion transmitted infection among blood donors at Jijiga blood bank, Eastern Ethiopia: retrospective 4 years study. BMC research notes, 9(1), 1-6.

10. Mutagoma, M., Remera, E., Sebuhoro, D., Kanters, S., Riedel, D. J., \& Nsanzimana, S. (2016). The prevalence of syphilis infection and its associated factors in the general population of Rwanda: a national household-based survey. Journal of sexually transmitted diseases, 2016. 